\title{
Varga Ágnes
}

\section{Társadalmi innováció mint horizontális eszköz szerepe az intelligens szakosodás megvalósulásában ${ }^{1}$}

A tanulmány célja, hogy a szakirodalom alapján rámutasson az intelligens szakosodás mint gazdaságfejlesztési koncepció megvalósitásában a társadalmi innovációk szerepére és indokoltságára. Az általában bottom-up módon kialakuló, a helyi igényekre reflektáló társadalmi innovációk, amelyek sokszor a gazdasági és technológiai innovációk nem kivánt negatív következményeinek megoldására irányulnak jól alkalmazhatók, és a kevésbé versenyképes régiókban szinte elengedhetetlenek az alapvetöen place-based intelligens szakosodási koncepció gyakorlati életben történö eredményes megvalósitásához. A tanulmány az intelligens szakosodás megjelenése és kapcsolódási pontjainak áttekintése mellett kitér a gazdasági szerkezetváltáshoz elengedhetetlen társadalmi tanulási folyamat és a hagyományos tudásrendszerek és közigazgatás kényszerü átalakulásának szükségességére a versenyképes gazdaság kialakitásának érdekében.

Kulcsszavak: versenyképesség, place-based megközelités, tudástranszfer, innováció JEL-kód: O35, F63, O00

https://doi.org/10.32976/stratfuz.2020.12

\section{Bevezetés}

Az Európai Unió a 2014-20 programozási ciklus kötelező elemévé tette - az Európai Regionális Fejlesztési Alap (ERFA) forrásainak lehívásához - az Intelligens Szakosodást Szolgáló Nemzeti/Regionális Innovációs Stratégiák ${ }^{2}$ (RIS3) megalkotását azzal a céllal, hogy megalapozza a rendelkezésre álló szükös források (támogatások, befektetések, hitelek) szinergikus módon történő, eredményorientált felhasználását, amelyet a régiók innovatív alapokon nyugvó gazdasági szerkezetátalakításával - a piaci résekre fókuszáló, az adott régió szempontjából adekvát területre történő szakosodással - képzel el. Célja, hogy a régiók láthatóvá váljanak a globális piacon a befektetők számára és érdemben járuljanak hozzá az Európai Unió az Amerikai Egyesült Államokhoz és Japánhoz (Grigolini et al. 2015) képesti 1995 óta megfigyelt teljesítménybeli lemaradásának megállításához (Ortega-Argilés 2012; van Ark et al. 2008).

A szakértők az Európai Unió lemaradásának okait elsősorban az infokommunikációs technológiában - mint korunk általános célú technológiájában (General Purpose Technologies, GPTs) - rejlö lehetőségeknek nem megfelelő szintü kiaknázásában látják, amelyet a versenytársak eredményesen alkalmaznak és hasznosítanak a szektorok és régiók közötti technológiai kapcsolatok kialakításában (Camagni - Capello 2017; McCann - Ortega-Argilés 2015).

A kutatások azt mutatták ki, hogy a versenytársak előnyében jelentős szerepet játszik magas szintű kutatási és innovációs eredményeik hasznosítása (Grigolini et al. 2015). Noha az európai tudósok teljesítménye világszinten is kiemelkedö, ez mégsem tükröződik megfelelő mértékben az Európai Unió gazdasági versenyképességében, amit a szakirodalom európai paradoxonként emleget (Horváth 2004; Pakucs - Papanek 2006). Amennyiben az Európai Unió a világ legversenyképesebb tudásalapú gazdaságává szeretne válni (lsd. Lisszaboni Stratégia, majd az Európa 2020) elengedhetetlen a $\mathrm{K}+\mathrm{F}$ politikák uniós szintủ erősítése és megvalósítása. Az Európai Unió a cél elérésének érdekében egy olyan nyitott, integrált és versenyképes Európai Kutatási Teret (European Research Area - ERA) igyekszik kialakítani, amely biztosítja a tudás, az ötletek és kutatók szabad áramlását a tagállamok között, elhárítván az európai kutatási „arénát”

\footnotetext{
${ }^{1}$ A tanulmány az EFOP-3.6.1-16-2016-00013 azonosítószámú „Intelligens szakosodást szolgáló intézményi fejlesztések a Budapesti Corvinus Egyetem Székesfehérvári Campusán” projektjének keretein belül jött létre.

${ }^{2}$ Research and Innovation Strategies for Smart Specialisation (RIS3)
} 
fragmentáló és versenyképességét gyengítő akadályokat és szabályozókat (Camagni - Capello 2017; Marimon - de Garca Carvalho 2008).

A Lisszaboni Stratégia megerősítéseként 2005-ben Janez Potočnik biztos elismert közgazdászokból megalapította a Knowledge for Growth csoportot, azzal a céllal, hogy a fejlesztéspolitika számára dolgozzanak ki egy olyan módszertant, amely megvalósítása révén a felhalmozott tudás hatékonyabban járulhat hozzá a fenntartható növekedéshez és a jóléthez. A módszertan továbbá foglalja magába a tudás létrehozásának, terjesztésének és felhasználásának előmozdításához szükséges politikák optimális kombinációját, és a tudásalapú társadalom kialakulásában szerepet játszó szereplők párbeszédének és együttműködésének erősítésére vonatkozó javaslatokat (EC 2008). A csoport a felkérésre az intelligens szakosodás koncepcióját dolgozta ki (Foray et al. 2009). A koncepció értelmében a régiók alapvetően egy bottom-up stratégiaalkotási folyamat során egy ún. vállalkozói tényfeltárásra (entrepreneurial discovery process) alapozva, a helyi erőforrások és tudás együttmüködések és közös gondolkodás révén történő aktivizálásával készítik el a helyi prioritásokra alapozott tudásintenzív iparágakra építő, gazdasági szerkezetváltást célzó fejlesztési terveiket, amelytől a térség globális értékláncokba történő bekapcsolódását, valamint a hazai és külföldi befektetők regionális megjelenését várják (EC 2014; Foray et al. 2012). Mivel a gazdasági növekedés és fejlődés egyik legszembetűnőbb kísérőjelensége általában a gazdasági tevékenység szerkezetének átalakulása (Szalavetz 2004), ezért ezen összefüggésre alapozva az intelligens szakosodási stratégia megvalósításának következtében fellépő gazdasági szerkezetátalakulástól a régió gazdasági növekedését várják.

Az intelligens szakosodás céljait tekintve vak a területi egyenlőtlenségekre, fó célja az európai régiók versenyképességének növelése, ezért is indokolt annak a kérdésnek az átgondolása, hogy vajon mely régiók azok, amelyek képesek lesznek a stratégia megvalósításához rendelt források révén gazdasági előnyre szert tenni, és melyek azok a régiók, amelyek (újra) kimaradnak és lemaradnak a globális versenyben.

A tanulmány a szakirodalom alapján arra a kérdésre keresi a választ, hogy az intelligens szakosodás logikájából levezethető előnyök vajon mely régiók és ágazatok számára jelentenek valódi előnyöket és mely esetben várható, hogy jelentősen hozzájárulnak a régión, tagállamokon és Európán belüli fejlettségbeli polarizációhoz, amely már most a jövő fejlesztéspolitikai kihívásait vetítik előre? Vajon a társadalmi innováció és társadalmi tanulás milyen szerepet játszik az intelligens szakosodás folyamatában, és mely formái azok, amelyek sikeresen alkalmazhatók az erőforráshiányos térségek esetén?

\section{Az intelligens szakosodás logikája és kapcsolódásai}

Az intelligens szakosodás koncepciója számos a fejlesztéspolitikában már ismert fejlesztési elmélet és eszköz új keretek közötti kombinációjával és megvalósításának újszerü megközelítésével operál. Az intelligens szakosodás koncepciója, a neoklasszikus elmélettel megegyezően a szakosodásban látja a gazdasági teljesítmény növekedésének kulcsát. Azonban míg a neoklasszikus elmélet amellett érvel, hogy a szakosodás jellege a megfelelö technológiai színvonal mellett szinte elhanyagolható, addig az intelligens szakosodás az evolúciós elméletekkel egyetemben hangsúlyozza, hogy a megfelelő gazdasági teljesítményhez elengedhetetlen a jó szakosodás (Szalavetz 2004), amely jelen esetben a régiókban már meglévő azon (hagyományos) szektorok tudásalapú innovatív megújítására koncentrál, ami elősegíti a régió globális értékláncokba történő bekapcsolódását, valamint jelentős spillover hatással bír egyéb kapcsolódó ágazatokban, és erőteljes vonzerőt jelent a hazai és nemzetközi befektetők számára.

Az intelligens szakosodás szakít az eddigi felülről vezérelt (top-down) és minden régió számára azonos célokat és eszközöket kínáló (one size fits all) regionális fejlesztéspolitikákkal és helyette egy a regionális sajátosságokra reflektáló (plase-based) politikát valósít meg, amely a helyi szereplőkben és hálózataikban meglévő tacit tudásra építve kívánja (bottom-up) a belső erőforrásokra alapozva (endogén és evolúciós megközelítés) meghatározott időre szóló fejlesztési céljait és cselekvéseit kitüzni. Az intelligens szakosodás tulajdonképpen egy célorientált politika 
(mission-oriented policy), amely szakít az eddigi neutrális szemléletü politikákkal és az elérhető belső és külső forrásokat egy cél elérésének - a gazdasági teljesítmény növekedés - érdekében kívánja mozgósítani (Foray 2018b). Az intelligens szakosodás lényegében a helyi tudásra és tanulási folyamatra épülő koncepció (McCann - Ortega-Argilés 2015). Korábban a regionális innovációs rendszerek modellje ugyan már elismerte annak szükségességét, hogy regionális szinten intézményi keretet kell kialakítani az innovációhoz, de a nagyrészt semleges politika nem volt érzékeny a regionális sajátosságokra (Foray 2018a; Vas - Bajmócy 2012).

$\mathrm{Az}$ intelligens szakosodás egyike annak a Radosevic (2017, idézi Lengyel 2018) által felvázolt hét - endogén alapokon nyugvó - új iparpolitikai ${ }^{3}$ megközelítésnek, amelyek kísérletet tesznek az ágazati (vertikális) és ágazattól független (horizontális) beavatkozások összehangolására (Lengyel 2018). Jelen esetben ez egyrészről a különböző ágazatokra, technológiákra és tevékenységekre összpontosító vertikális prioritások meghatározásában testesül meg az olyan általános prioritások helyett, mint például az együttműködés ösztönzése a kutatás és az iparágak között, vagy a humán tőke bevonása. Másrészről horizontálisan szorgalmazza a piaci versenybe való bekapcsolódás és a vállalkozói ismeretek ötvözését a tudományos, technológiai és mérnöki képességekkel, valamint a piaci változások és az üzleti igények ismeretével (EC 2014).

A cél jelen esetben a régiók globális versenybe történő eredményes bekapcsolódása, amelyet a $\mathrm{K}+\mathrm{F}+\mathrm{I}-\mathrm{re}$ alapozott fókuszált gazdasági szerkezetátalakítással kíván elérni. Fókuszált, mert nem a régió teljes gazdasági szerkezetátalakítására törekszik, hanem csak azokra a területekre koncentrál, amelyek segítik a régiót a kitüzött cél elérésében. Az intelligens szakosodás céljának elérése érdekében olyan egymáshoz kapcsolódó területeken gyüjti össze a régióban meglévő (vagy más régiókkal folytatott belső munkamegosztás és együttmüködés útján birtokolt) erőforrásainak kritikus tömegét, amelyek megfelelő lendületvétel után a régiót önellátóvá teszik. A politika e folyamatot a tudásalapú szolgáltatások és infrastruktúra, valamint az emberi erőforrások fejlesztése révén kívánja támogatni (EC 2014).

Az intelligens szakosodás eszközeként megjelenő már meglévő, hagyományos szektor modernizálásának gondolata nem újdonság a fejlesztéspolitikában, azonban annak az intelligens szakosodási stratégiák (S3) által felvázolt módja igen (Foray 2018a). Valójában az S3 nemcsak a hagyományos iparágakra koncentrál, hanem a $\mathrm{K}+\mathrm{F}+\mathrm{I}-\mathrm{n}$ alapuló gazdasági szerkezetátalakításra helyezi a hangsúlyt. A regionális S3 megalkotása során azonban a legtöbb európai régió a hagyományos ágazatainak korszerüsítését tüzte ki célul az innovációs folyamatok erősítése és az azt támogató immateriális javak (pl: képzés, menedzsment, speciális szolgáltatások) fejlesztése révén, így a koncepció által szorgalmazott eredeti célok csorbultak (Foray 2018a).

A politika megvalósításában a vállalkozásoknak kiemelkedő szerepe van, hiszen a régió a helyben lévő, vagy újonnan betelepülő vállalkozások révén tud bekapcsolódni a globális versenybe, és a központi támogatásokon kívül a regionális és régión kívüli (nemzetközi) befektetések adják a fejlesztéshez szükséges tőkét. Ezért a quadruple hélix ${ }^{4}$ alapján egy vállalkozói tényfeltárás során kerülnek azonosításra azok az ún. transzformációs tevékenységek (transformative activity), amelyektől az adott régió gazdasági szerkezetváltozását várják. A transzformációs tevékenység tehát az intelligens szakosodás koncepció központi elemeként jelenik meg, amely nem egy önálló projekt, és nem is feltétlenül egy teljes szektort fed le, hanem a régióban már meglévő innovációs kapacitások és cselekvések azon gyüjteménye, amely a régió versenyképességének növeléséhez hozzájáruló új lehetőségek feltárásához szükséges cselekvésekre koncentrál, és elősegíti az innovációban résztvevő szereplök közötti kollektív cselekvések kibontakozását (Foray 2018a, 2018b). A transzformációs tevékenység adott esetben csupán az érintettek közötti kapcsolatok elősegítésében manifesztálódik, amely megkönnyíti a túlcsordulást, vagy katalizátorként szolgálhat a vállalatok, beszállítók és kutató partnerek együttes

\footnotetext{
${ }^{3}$ new industrial policies (NIP)

${ }^{4}$ Az üzleti szférát, a kutatási és oktatási intézményeket, a közigazgatást, valamint a civil szervezeteket és állampolgárokat tömörítő érintett szereplői csoportok elnevezése.
} 
cselekvéseihez (Foray 2018a). Az így kialakított tevékenységi portfóliót regionális szinten menedzselik és a változásokra folyamatosan reflektálva módosítják azt.

A gazdasági növekedés fő mozgatórugója jelen esetben is a technológiai változás (Bekar et al. 2018), amelyek közül kiemelkedők a társadalmi-gazdasági rendszerben átfogó és radikális változást elindító általános célú technológiák (Hámori - Szabó 2018). A gazdasági tevékenység számos területét és különböző funkcióit átható általános célú technológiák sajátos tulajdonságai egy olyan keretrendszert definiálnak (1.táblázat), amely segít tisztázni az intelligens szakosodás logikáját és a megvalósulásával kapcsolatos fejlesztéspolitikai elvárásokat (Foray et al. 2009).

\section{1.táblázat: Az általános célú technológiák közös jellemzői}

Általános célú technológiák (GPT) jellemzői

- Innovációs hullámokat indítanak el, amelyek szinte fertőzésszerűen terjednek a gazdasági szervezetek, gazdasági ágak, országok, régiók között;

- Beérésükkor drámaian csökkentik a javak és szolgáltatások előállításának a költségeit, lényegesen növelik a gazdaság hatékonyságát;

- A változások nem maradnak a gazdaságon belül, hanem kihatnak a társadalmi élet számos területére, az emberi érintkezésre és a társadalom szerveződésére is;

- Nem egyszerre bukkannak fel a semmiből, általában hosszú kihordási szakasz előzi meg őket. Ebben a szakaszban gyakran nem ismerik fel jelentőségüket, s a korábbi korszak fogalmaiban értelmezik őket;

- Hatásaik hosszú távúak, generációk életét befolyásolják;

- Fontos (mellék)hatásuk, hogy megjelenésük növeli a turbulenciát és a bizonytalanságot, minthogy átrendezik a szakmastruktúrát, meggyorsítják a hagyományos termelők, funkciók kiszorulását a gazdaságból;

- Hatásukra lázas átrendeződés zajlik a gazdaság alapegységeiben, sőt új alapegységek válnak dominánssá;

- Lényegesen hatnak az adott társadalmi rendszer müködésére, sőt akár új társadalmi rendszer kialakulásának elindítói lehetnek.

\section{Forrás: Hámori - Szabó 2018}

A kapitalizmus logikájából következik, hogy sikeres gazdaság csak innovatív gazdaság lehet (Hámori - Szabó 2018; Kornai 1999). Az intelligens szakosodás tulajdonképpen regionális léptékben épít a GPT szerü tulajdonságokkal bíró megjelenő és tovagyürüző innovációkra. $\mathrm{Az}$ intelligens szakosodási stratégiák központi elemét jelentő transzformációs tevékenységek kijelölése kapcsán Foray (2018a, 2018b) a következő elvekre hívja fel a figyelmet.

- Az innovációt tágan kell értelmezni, vagyis az nem pusztán a high-tech-re és a technológiai innovációra korlátozódik (Foray et al. 2012), hiszen számos régió esetén nem új dolgokat kell bevezetni, hanem a meglévő ágazatokban folyó innovációs tevékenységet kell kiegészíteni a siker érdekében. Így a képzések, új vezetői és mérnöki készségek kialakítása éppúgy a tevékenységek között lehet, mint a minőség-ellenőrzés, vagy tanúsítványok, illetve a technológiák széles körben történő elfogadtatása.

- Technológiai oldalon az általános célú technológiák (GPT) központi szerepet kell kapjanak, amelyekhez társuló technológiák fejlesztését már a nem tudásrégiók (1. ábra) is eredményesen használhatják versenyképességük növeléséhez.

- Szem elött kell tartani, hogy ne csak a $\mathrm{K}+\mathrm{F}+\mathrm{I}$ projektek támogatására, de a projektek végrehajtásához szükséges munkaerő képzésére is kellö figyelmet fordítsanak, különben a $\mathrm{K}+\mathrm{F}+\mathrm{I}$ szektor által támasztott munkaerő iránti kereslet csak a munkavállalók bérének emelkedését fogja eredményezni, és nem a $\mathrm{K}+\mathrm{F}+\mathrm{I}$ szint növekedését (Romer 2000).

- A transzformációs tevékenységnek integrálnia kell az innovációs célok elérésében nagy szerepet játszó, az alkalmazott technológia széles körben történő elterjesztésére 
vonatkozó cselekvéseket is, különben a megjelenő innováció nem vezet valódi regionális átalakuláshoz, pusztán az induló vállalkozásokra fog korlátozódni.

\section{Társadalmi innovációk, tanuló régiók és a közszféra szerepe az intelligens szakosodásban}

Társadalmi innovációk és intelligens szakosodás közös jellemzője a többszintű megközelítés, így a társadalmi innováció bekerült az S3 megvalósulását hatékonyan támogatni tudó megvalósítási eszközök közé, valamint megjelent a hazai ágazatokat átívelő, horizontális prioritások között is (NIH 2014; Nogueira et al. 2017).

A társadalmi innováció fogalma ugyan az utóbbi időben mind a tudományos, mind a fejlesztéspolitikai szakma központi fogalmai között szerepel mégsem alakult ki egységes definíciója, amely árulkodik a fogalom összetettségéről és az értelmezése körüli bizonytalanságokról. Egy a különböző társadalmi innovációs fogalmak összehasonlító elemzését vizsgáló kutatás (EC 2013) 17 különböző uniós finanszírozású, társadalmi innovációval kapcsolatos kutatást vizsgált azzal a céllal, hogy feltárja a társadalmi innováció értelmezését az európai kutatói mühelyek munkájában és a tudományos diskurzusban. A kutatás megállapítja, hogy a társadalmi innovációs definíciók közötti lényegi különbség az, hogy a társadalom milyen szerepben jelenik meg az innováció folyamatában: az innováció megalkotójaként, az innováció céljaként, vagy az innovációs megoldás természetét befolyásoló dimenzióként. Jelen tanulmányban egy korábbi tanulmányunkkal azonos (Nemes - Varga 2015b) értelemben használom a társadalmi innováció fogalmát. Vagyis a fogalmat kitágítom és társadalmi innovációnak tekintek minden olyan új, az eddigi gyakorlattól eltérő szemléletet, megközelítést, paradigmát, illetve az ezekhez kapcsolódó terméket, eljárási folyamatot, gyakorlatot, hálózatot, amelyek a társadalomban felmerülő problémák és szükségletek megoldását célozzák, miközben új értékek, attitüdök, új társadalmi kapcsolatok, esetleg új struktúrák jönnek létre. Az általában bottom-up módon kialakuló, a helyi igényekre reflektáló társadalmi innovációk, amelyek sokszor a gazdasági és technológiai innovációk okozta társadalmi problémák megoldására irányulnak (Benedek et al. 2015; Kocziszky et al. 2017; Lipták - Horváth 2018) módszertanukban számos az intelligens szakosodás megvalósításához.

A társadalmi problémák megoldása éppúgy strukturális változásokat igényel, mint a gazdasági növekedés, ezért az intelligens szakosodás végrehajtása során a társadalmi innováció logikája és megvalósulása (Kocziszky et al. 2017; Nagy 2019) fontos eszközzé válhat a társadalmi igények, a társadalom aktivizálása és a gazdaságfejlesztés terén egyaránt (Katonáné Kovács Varga - Nemes 2017). A társadalmi innovációt olyan eszközként jelöli meg az S3 útmutató, amely képes integrálni a társadalmi szükségletek és kihívások kezelésében érdekelt különbözö szereplőket. A társadalmi innováció általában olyan megoldásokat kínál a problémák kezelésére, amelyek hatékonyabbak és kevesebb erőforrást igényelnek, mint a hagyományos, top-down megoldások. A társadalmi innováció létrejöttének folyamata segíti az intelligens szakosodás folyamatának kibontakozását a helyi problémák és erőforrások feltárásában, a tacit tudások felszínre hozásában, a helyi környezetben új és/vagy eladható termékek, szolgáltatások kifejlesztésében, a lehetséges piacok megtalálásában. Továbbá jelentősen hozzájárulhat a szükséges kapcsolatok, társadalmi, együttmüködési hálózatok kiépítéséhez, hiszen a fejlesztéshez sokszor új társakra, de legalábbis a régi kapcsolatok megújítására, új tartalommal való feltöltésére van szükség (Nemes - Varga 2015b).

Az intelligens szakosodás mind a stratégiaalkotás, mind annak megvalósítása során nagyban épít a helyi szereplők együttmüködésére, az abból származó tudástranszferre és innovációra. Tulajdonképpen az intelligens szakosodás a kiemelt célok mentén az adott régiót tanuló régiónak ${ }^{5}$

\footnotetext{
${ }^{5}$ A tanuló régiók olyan régiók, ahol a régióban található személyek, szervezetek, intézmények stb. esetében tanulásokat azonosíthatunk, amely tanulási folyamat túlmutat az adott térségben jelen lévő intézményesített oktatási rendszeren (közoktatás, felsőoktatás, felnőttképzés és felnőttoktatás), amely oktatási rendszer (mennyisége és minősége) szükséges, de nem elégséges feltétele a sikeres tanuló régióvá válásnak. Akkor lesz egy térség sikeres tanuló régió, ha az intézményesített oktatási kereteken kívül is megvalósul a tanulási folyamat olyan esetekben, amikor olyan tudásra van
} 
tekinti, ahol az innováció a régióban meglévő különböző hálózatok és szervezetek közötti tudástranszfer eredményeként áll elő (2. táblázat). Vagyis az innováció fogalmát nemcsak széles értelemben használja, hanem létrejöttének módját tekintve szakít az eddigi politikákban megfigyelhető lineáris megközelítéssel, és sokkal inkább a rendszerszintü megközelítést alkalmazza, amelyben a hagyományos tudásrendszer elemeinek szerepe és helye a tudás és innováció elöállításában megváltozik (Nemes - Varga 2015a), amelyben nagyobb szerephez jutnak a hálózatok és szervezetek közötti infomális kapcsolódási pontokon kialakuló innovációk. Jelen szakpolitika épp ezért mindazon cselekvéseket is transzformációs tevékenységnek minősíti, amelyek az ilyen jellegü kapcsolatok és tudástranszferek sürüségét növelik a régióban.

\section{2.táblázat: Tanuló régiók és az őket befolyásoló tudásvezérelt gazdasági fejlődés jellemző} folyamatai

\begin{tabular}{|c|c|c|}
\hline $\begin{array}{l}\text { Tudásvezérelt gazdasági } \\
\text { fejlődés }\end{array}$ & $\begin{array}{l}\text { Tudás/innováció } \\
\text { megszületése }\end{array}$ & Tanulási folyamat \\
\hline $\begin{array}{l}\text { - csúcstechnológián alapuló, } \\
\text { tudásintenzív ágazatok } \\
\text { - gazdaság alapja a tudás és a } \\
\text { tanulás } \\
\text { - tanulás és innováció együtt } \\
\text { jár } \\
\text { - munkavégzés folyamatos } \\
\text { tanulást igényel }\end{array}$ & $\begin{array}{l}\text { - hálózatok kapcsolódási } \\
\text { pontjainál } \\
\text { - kiemelt szerepe van a } \\
\text { társadalmi tőkének } \\
\text { - heterogén hálózatok } \\
\text { kedvezőbbek } \\
\text { - a helyhez kötődő tacit tudás } \\
\text { értékesebb }\end{array}$ & $\begin{array}{l}\text { - nem formális, nem } \\
\text { szokványos módok } \\
\text { különbözö alternatívái } \\
\text { - interaktív } \\
\text { - együttmüködésekben } \\
\text { valósul meg } \\
\text { - IKT eszközökkel növelt } \\
\text { hatékonyság }\end{array}$ \\
\hline
\end{tabular}

Forrás: Kozma et al. 2015 alapján saját szerkesztés

Az intelligens szakosodás bottom-up jellegéből adódóan, és az innováció kialakulásának nem lineáris értelmezése következtében, kényszerüen meg kell, hogy változzon a közszféra pozíciója és szerepe is (Foray et al. 2009). Az intelligens szakosodás, mint minden célorientált és nemsemleges politika kísérletező jellegü, ugyanis politikailag kockázatos döntések meghozatalát és folyamatok támogatását igényli (ellentétben például a $\mathrm{K}+\mathrm{F}$-et alkalmazó vállalkozások számára nyújtott adójóváírás, mint ösztönző bevezetésével). A folyamat két szinten is kockázatot hordoz, egyrészről az egyedi projektek sikeressége, másrészről a transzformációs tevékenységek hatásosságában a gazdasági szerkezetátalakítás terén. Épp ezért az ilyen jellegű politikák megvalósításának nagyobb a költsége, és jelentős átalakulást igényel a közszféra részéröl: egy olyan hozzáállást, amely jól tudja kezelni az előre nem látható tényezőkből adódó bizonytalanságot, kellően rugalmas, és felkészült, hogy egy iteratív folyamat keretein belül a változó valósághoz és növekvő kudarckockázatokhoz mérten módosítani tudja az eredeti elképzeléseket (Foray 2018b).

Az intelligens szakosodás láthatóan komplex problémát igyekszik kezelni, ami egy olyan sokszereplős közegben valósul meg, ahol az érintett szereplők között dinamikus kölcsönös függőségeket feltételezhetünk, amelyek sikeres menedzselése a többszereplős kormányzás kialakulásának és kultúrájának irányába mozdítja el a közszférában meglévő struktúrákat (Craps et al. 2019).

Az intelligens szakosodás által képviselt rendszerben a közszféra, az egyetemek, kutatóintézetek és szakképzés helye és szerepe is megváltozik. Míg a közszféra sokkal inkább egy támogató szerepbe kerül, amely a megfelelő körülmények biztosítását és egyfajta koordinációt, a lehetőségek feltérképezését végzi, valamint a folyamathoz szükséges társadalmi tőke megteremtését segíti elő (Bodor 2013), addig a kutatóintézeteknek és egyetemeknek sokkal

szükség, amelyet az intézményesített oktatási rendszer nem tud biztosítani, és azt az érintettek más úton szerzik meg, vagy állítják elő (KOZMA et al. 2015). 
szorosabb viszonyt kell ápolniuk a piaci szereplőkkel, akik számára ki kell elégíteni a képzett munkaerő és az innovációkhoz kapcsolódó tudás előállítás igényét.

\section{Erőforráshiányos térségeink intelligens szakosodási esélyei}

Az intelligens szakosodási stratégia által támogatni kívánt folyamatok megfelelő vállalkozói és menedzsment képességek mellett természetesen spontán és decentralizált módon is lejátszódnak, azonban ha ezek túl gyengék, vagy az új transzformatív tevékenység kialakításának kihívásai túl nagyok, akkor a fent leírt folyamatok spontán módon nem fognak megtörténni (Foray 2018a). A szakpolitika azokban a térségekben lehet eredményes - és ott van rá szükség -, ahol jelen van az erőforrások kritikus tömege, de a kedvező folyamatok beindításához támogatásra van szükség. Azonban a RIS3 is szembe fog nézni a hazai bottom-up politikák megvalósítása terén tapasztalat nehézségekkel. Az intelligens szakosodás koncepcióját eredetileg nem kötötték régióhatárokhoz, azt az európai tervezési gyakorlat alakította csak így. Ahogy arra Dőry (2001) még a neutrális innovációs politikák kapcsán felhívta a figyelmet a legnagyobb kihívást az fogja jelenteni az intelligens szakosodás számára is, hogy egyensúlyt alakítson ki az adottságok és a régió $\mathrm{K}+\mathrm{F}$, illetve innovációs igényei között, ami várhatóan sikeresebb lehet az intelligens szakosodás logikájából következően, mint a korábbi regionális innovációs stratégiák esetén.

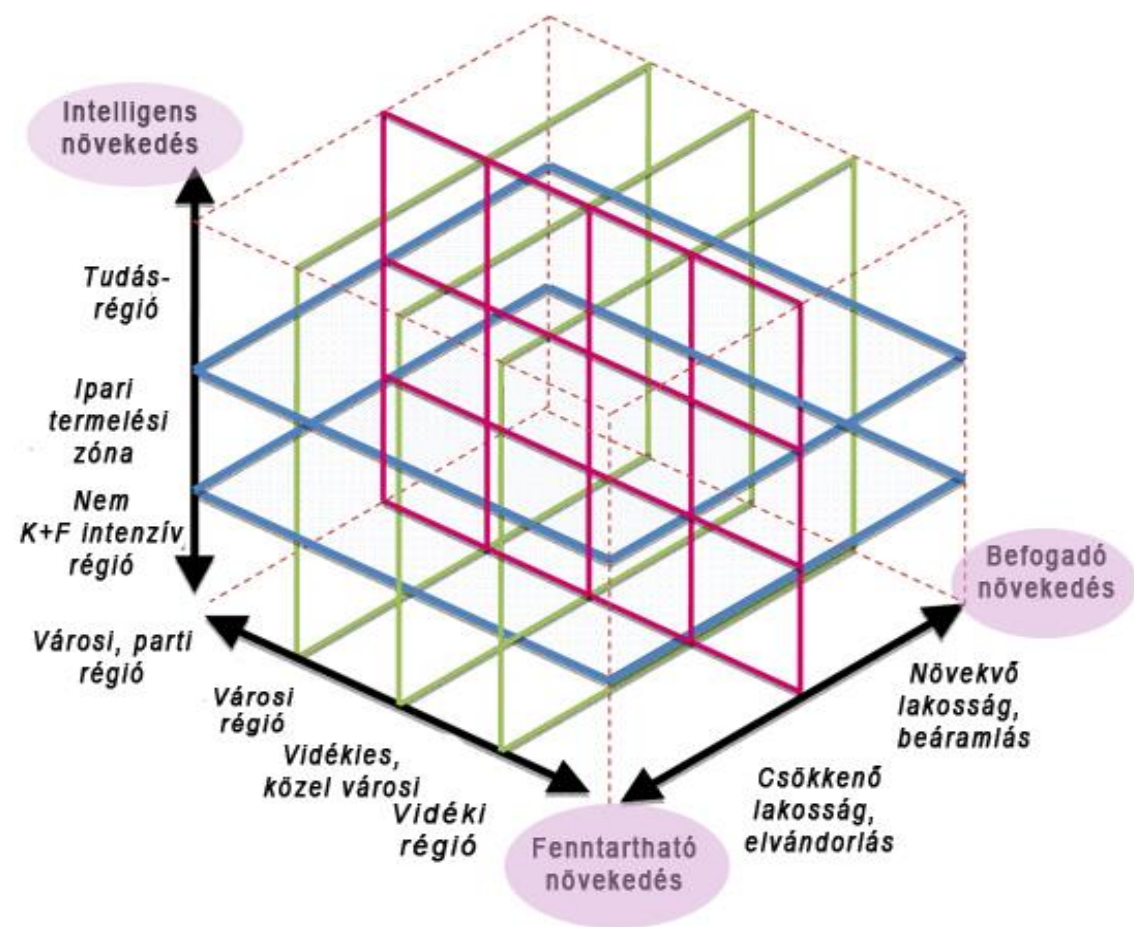

1.ábra: Régiók tipizálásához használt térmátrix

Forrás: NIH, 2014

3. táblázat: Hazai megyék régiótípusok szerint

\begin{tabular}{|l|l|lr} 
Tudásrégiók & Ipari termelési zónák & $\begin{array}{l}\text { Alacsony tudás- és } \\
\text { technológia intenzív } \\
\text { régiók }\end{array}$
\end{tabular}




\begin{tabular}{l|l|l|l} 
Észak-Magyarország & & Borsod-Abaúj-Zemplén & Heves, Nógrád \\
\hline Észak-Alföld & Hajdú-Bihar & Jász-Nagykun-Szolnok & $\begin{array}{l}\text { Szabolcs-Szatmár- } \\
\text { Bereg }\end{array}$ \\
\hline Dél-Alföld & Csongrád & Bács-Kiskun & Békés \\
\hline Közép-Dunántúl & Veszprém & Fejér & Zala \\
\hline Nyugat-Dunántúl & & $\begin{array}{l}\text { Györ-Moson-Sopron, } \\
\text { Vas }\end{array}$ & Somogy, Tolna \\
\hline Dél-Dunántúl & Baranya & \multicolumn{2}{|l}{$\begin{array}{l}\text { Forrás: NIH, 2014 alapján saját szerkesztés }\end{array}$}
\end{tabular}

Hazánkban a NUTS2-es, de még a NUTS3-as szintü közigazgatási egységek S3 szerinti régiótípusokba sorolása is erősen heterogén területi egységeket jelent (3. táblázat). A tudásrégiók, de az ipari termelési zónák esetén is legtöbbször a nagyobb városok, vagy a megyeszékhely, amely a $\mathrm{K}+\mathrm{F}$ bázist jelentik, és a megyében található vidéki térségek az alacsony tudás- és technológiaintenzitású, vagy azt el nem érő régió típusba sorolhatók (1.ábra). Előbbi esetén gondoljunk csak Csongrád, míg utóbbi esetén Borsod-Abaúj-Zemplén megyére. Ebből következően - akárcsak a versenyképesség (G. Fekete 2008)-, úgy az intelligens szakosodás értelmezését és kifutását is újra kell gondolni kevésbé innovatív térségek esetén. E területek szempontjából, amennyiben nem történik meg az S3 saját körülményeikhez történő adaptálása, akkor az egy olyan szakpolitika ${ }^{6}$ marad, amely még inkább növeli lemaradásukat a többi régióhoz, vagy a régión belüli kedvezöbb adottságokkal rendelkező térséghez képest.

$\mathrm{Az}$ erőforráshiányos térségek esetén a tervezés, de különösen a megvalósítás során nehézséget jelent (1) a magánszféra alacsony $\mathrm{K}+\mathrm{F}$ ráfordítása $-\mathrm{az}$ állam által finanszírozott intézmények még itt is működnek - (2) az alacsony szintü technológia transzfer az állami kutatóközpontok, felsőoktatási intézmények és a magánszféra, illetve a vállalkozások között kultúrájának és intézményeinek hiánya - (3) gyenge vagy hiányzó együttmüködés a regionális $\mathrm{K}+\mathrm{F}$ központok és a nemzeti kutatóhálózatok között (Dőry 2001).

4.táblázat: A hazai Nemzeti Intelligens Szakosodási Stratégia horizontális és ágazati prioritásai

Befogadó és fenntartható társadalom, élhető környezet

\begin{tabular}{|c|c|c|c|c|c|}
\hline \multicolumn{6}{|c|}{ IKT (infokommunikációs technológiák) és szolgáltatások } \\
\hline $\begin{array}{l}\text { Egészséges } \\
\text { társadalom } \\
\text { és jólét }\end{array}$ & $\begin{array}{l}\text { Fejlett jármü- } \\
\text { és egyéb } \\
\text { gépipari } \\
\text { technológiák }\end{array}$ & $\begin{array}{l}\text { Tiszta és } \\
\text { megújuló } \\
\text { energiák }\end{array}$ & $\begin{array}{l}\text { Fenntartható } \\
\text { környezet }\end{array}$ & $\begin{array}{l}\text { Egészséges és } \\
\text { helyi } \\
\text { élelmiszerek }\end{array}$ & $\begin{array}{l}\text { Agrár- } \\
\text { innováció }\end{array}$ \\
\hline
\end{tabular}

Forrás: NIH, 2014 alapján saját szerkesztés

A hazai Nemzeti Intelligens Szakosodási Stratégia (NIS3) három nemzeti specializációt, hat vertikális és két horizontális prioritást jelöl meg (4. táblázat). Az 5. táblázatban látható, hogy az egyes specializációk nem azonos hatásfokúak a különböző régió-típusokban.

\section{5.táblázat: Nemzeti intelligens szakosodási stratégia specializációinak régió-típusok szerinti hasznosulása (\%)}

\begin{tabular}{|l|l|l}
$\begin{array}{l}\text { Rendszerszemléletű } \\
\text { kutatás }\end{array}$ & Intelligens gyártás & $\begin{array}{l}\text { Fenntartható } \\
\text { társadalom }\end{array}$
\end{tabular}

\footnotetext{
${ }^{6}$ Természetesen az S3 mellett továbbra is életben vannak más ágazati, vagy területi politikák, de kiegészítő politikaként az S3 az erősebbeket fogja tovább erősíteni.
} 


\begin{tabular}{l|l|l|l} 
Tudásrégiók & 70 & 20 & 10 \\
\hline Ipari termelési zónák & 20 & 60 & 20 \\
\hline $\begin{array}{l}\text { Alacsony tudás- és } \\
\text { technológia- } \\
\text { intenzitású régiók }\end{array}$ & 10 & 20 & 70
\end{tabular}

Forrás: NIH, 2014 alapján saját szerkesztés

A tudásrégiókban a rendszerszemléletủ kutatások a legjobb hatásfokúak, ahol az akadémiai szektor határozza meg a $\mathrm{K}+\mathrm{F}+\mathrm{I}$ teljesítményt, ami mellett néhány $\mathrm{K}+\mathrm{F}$ intenzív nagyvállalat is hozzájárulhat a régióban egy létező szektor együttmüködő intézményeken és folyamatokon alapuló átalakulásához. Az intelligens gyártás az ipari termelési zónák esetén a legjobb hatásfokú, ahol a $\mathrm{K}+\mathrm{F}$ tevékenységek középpontjában a termékfejlesztés áll és a feldolgozóipar és az intenzív vállalati $\mathrm{K}+\mathrm{F}$ dominál egy létező iparág modernizációjának érdekében. Az alacsony tudás- és technológia-intenzív régiókban a társadalmi kihívások jelentik a legfőbb problémát, ahol elsődleges cél a fenntartható társadalom támogatása oly megoldások révén, amelyek egy új és egy régi tevékenység szinergiáiból adódó előnyöket igyekeznek kihasználni egy hagyományos terület radikális újraalapozásával (NIH, 2014). Utóbbi esetben kiemelt szerephez juthat a társadalmi innováció, amely a hazai NIS3 esetén a Befogadó és fenntartható társadalom, élhető környezet horizontális prioritás eszközeként jelenik meg (4.táblázat).

Az alacsony tudás- és technológia-intenzitású régiók esetén sok esetben a helyi erőforrásokra sokoldalúan támaszkodó fenntartható mezőgazdaságon és vidékfejlesztésen keresztül vezet az út a fenntartható társadalom kialakításához (G. Fekete 2015). A hat ágazati prioritás közül az Agrárinnováció és az Egészséges és helyi élelmiszerek járulhatnak hozzá leginkább a helyi társadalom és gazdaság vitalizálásához. Megfigyelhető, hogy az ágazati innovációk elsősorban technológiai innovációk, pedig a gazdasági struktúraváltáshoz a társadalmi gyakorlatok megváltozására és tanulásra is szükség van, amelyre a mezőgazdaságban jó példaként szolgálnak a tanuló és innovációs hálózatok az alacsony tudás- és technológia-intenzitású régiók intelligens szakosodásában.

A mezőgazdaságban Európa szerte megfigyelhető jelenség, hogy a fenntarthatóság irányába történő elmozdulás számos olyan kérdést vetett fel, amelyre a hagyományos mezőgazdasági tudásrendszer nem, vagy nem elég gyorsan reagált (Nemes - Varga 2015a). E problémák mentén olyan alulról szerveződő tanuló közösségek alakultak, amelyek a problémák megoldását a közösségen belüli tudásmegosztás révén, a különböző tudással rendelkező szereplök interakciójában és kapcsolati hálóját felhasználva igyekeztek megtalálni, és beágyazottságuktól függően inkrementális, vagy radikális innovációk révén strukturális változásokat igyekeztek elérni a meglévő rezsimben csakúgy mint az S3. A témában 2011 és 2014 között zajlott egy FP7-es (SOLINSA) kutatás - amely a hálózatok müködési sajátosságait, valamint céljaik elérésének akadályait igyekezett feltérképezni, annak érdekében, hogy a fejlesztéspolitika számára ajánlásokat fogalmazzon meg, hogy az miképpen tudná támogatni e szervezetek müködését és a bennük végbemenő tanulási és innovációs folyamatot, amely nagymértékben hozzájárul a mezőgazdaság átalakulásához szükséges szerkezetváltáshoz. A kutatás tárgyát farmerekből, termelőkből, fogyasztókból, NGO-kból, szakértőkből és helyi közigazgatáshoz kapcsolódó entitásokból (egyének, vagy szervezetek is lehetnek) álló hálózatok (Learning and Innovation Networks for Sustainable Agriculture (LINSA)) képezték, amelyek alternatív utakat kerestek az élelmiszertermelés és egyéb a fenntartható mezőgazdaság és vidékfejlesztés megvalósulásához hozzájáruló területeken (Brunori et al. 2013). Véleményem szerint az erőforráshiányos területeken a föként a központra összpontosító intelligens szakosodási stratégiák pozitív hatásainak kiaknázásában nagy szerepet játszhatnak a helyben újonnan kialakuló, vagy - az intelligens szakosodás szellemiségében - a meglévő térségi fejlesztési szervezetek revitalizálása révén létrejövő helyi hálózatok és partnerségek, amelyek a régióban meglévő tudásközpontokkal (pl: egyetemekkel) együttmüködésben a térségben azonosított társadalmi kihívásokra igyekeznek minél hatékonyabb választ találni (NGM, 2013). E szervezetek innovációk révén történő 
megújulásának közösségi tervezésen alapuló támogatása kiemelten fontos lenne a központi politika részéröl a helyi alternatív fejlesztési irányok és eszközök kibontásának érdekében, amelyek fejlődési tapasztalatai értékes eredményekkel járulhatnának hozzá a központi politika továbbfejlesztéséhez is.

\section{Összefoglalás}

A régiók versenyképességének az intelligens szakosodás koncepciójának megvalósítása révén történő fokozása a kedvezőbb tőkeellátottságú régiókban is a meglévő tudásrendszerek és közigazgatási gyakorlat átalakulását kívánja a módszertan által sugallt - az addigi lineáris megközelítéssel szakító - fejlesztéspolitika kísérletező, útkereső és alapvetően együttműködésen alapuló jellege következtében. Az új rendszerszemléletű megközelítésben a hagyományos tudásrendszer elemeinek szerepe és helye a tudás és innováció elöállításában megváltozik, amelyben nagyobb szerephez jutnak a hálózatok és szervezetek közötti infomális kapcsolódási pontokon kialakuló innovációk. A társadalmi innováció olyan eszköz, amely képes integrálni a társadalmi szükségletek és kihívások kezelésében érdekelt különböző szereplőket, és ezáltal az intelligens szakosodás rendszerszintü megközelítésének adekvát eszközévé válik.

Az S3 célja nem új dolgok bevezetése, hanem a meglévő ágazatokban folyó innovációs tevékenység megfelelő tartalmakkal (képzések, minőség-ellenőrzés bevezetése, technológiák terjesztése, szükséges hálózatok kialakítása és müködési gyakorlatának kidolgozása) történő kiegészítése a régiók globális értékláncokba történő bekapcsolásának érdekében. Mindehhez elengedhetetlen a helyben meglévő tacit tudás becsatornázása és a versenyképesség útjában álló problémák partnerségen alapuló feltárása, valamint a megoldási stratégiák iteratív, folyamatos önreflexión alapuló fejlesztése. A társadalmi innováció általában olyan megoldásokat kínál a problémák kezelésére, amelyek hatékonyabbak és kevesebb erőforrást igényelnek, mint a hagyományos, top-down megoldások. A társadalmi innováció létrejöttének folyamata segíti az intelligens szakosodás folyamatának kibontakozását a helyi problémák és erőforrások feltárásában, a tacit tudások felszínre hozásában, a helyi környezetben új és/vagy eladható termékek, szolgáltatások kifejlesztésében, a lehetséges piacok megtalálásában. Továbbá jelentősen hozzájárulhat a szükséges kapcsolatok, társadalmi, együttmüködési hálózatok kiépítéséhez, hiszen a fejlesztéshez sokszor új társakra, de legalábbis a régi kapcsolatok megújítására, új tartalommal való feltöltésére van szükség.

A társadalmi innovációk azonban különösen felértékelődnek az alacsony tudás- és technológia-intenzív régiókban, ahol a versenyképesség fokozásához szükséges piaci résekre fókuszáló területeket sokszor ki kell találni, vagy egy hagyományos területet radikálisan újra kell gondolni (l. biogazdaságok, helyi termékek) és sikeres piaci alapokon történő müködtetésükhöz a térségi hálózatokban történő müködés (l. hütőházak, integrátorok, géppark). Az alacsony tudásés technológia-intenzitású régiók esetén az S3 megvalósításában a társadalmi innováció mint fejlesztési eszköz erősen felértékelődik, hiszen az csak a legnagyobb problémát jelentő társadalmi kihívások kezelésén keresztül képzelhető el, amelynek a helyi erőforrásokra sokoldalúan támaszkodó fenntartható, multifunkcionális mezőgazdaság és integrált vidékfejlesztés eredményes eszköze lehet.

\section{Irodalomjegyzék}

BEKAR, C. - CARLAW, K. -LIPSEY, R. (2018): General purpose technologies in theory, application and controversy: A review, Journal of Evolutionary Economics, 28, pp. 1005-1033. https://doi.org/10.1007/s00191-017-0546-0 
BENEDEK J. - KOCZISZKY GY. - VERESNÉ SOMOSI M. - BALATON K. (2015): Regionális társadalmi innováció generálása szakértői rendszer segítségével, Északmagyarországi Stratégiai Füzetek, XII (2), pp. 4-22.

BRUNORI, G. - BARJOLLE, D. - DOCKES, A.-C. - HELMLE, S. - INGRAM, J. - KLERKX, L. - MOSCHITZ, H. - NEMES, G. - TISENKOPFS, T. (2013): CAP Reform and Innovation: The Role of Learning and Innovation Networks, EuroChoices, 12(2), pp. $27-$ 33. https://doi.org/10.1111/1746-692X.12025

CAMAGNI, R. - CAPELLO, R. (2017): Regional Innovation Patterns and the EU Regional Policy Reform: Towards Smart Innovation Policies. In Capello, R. (szerk.): Seminal Studies in Regional and Urban Economics, Springer, pp. 313-344. DOI 10.1007/978-3-319-578071

DŐRY T. (2001). Az innováció kutatások megjelenése a regionális elemzésekben-Az innováció regionális perspektívában, Tér és Társadalom, XV (2), pp. 87-106.

EC (European Commission) (2014): Az intelligens specializációt szolgáló nemzeti/regionális innovációs stratégiák (RIS3), p.8.

EC (European Commission) (2013): Social innovation research in the European Union: Approaches, findings and future directions, Publications Office of the European Union

FORAY, D. (2018a): Smart specialisation strategies and industrial modernisation in European regions-Theory and practice, Cambridge Journal of Economics, 42, pp. 1505-1520. https://doi.org/10.1093/cje/bey022

FORAY, D. (2018b): Smart specialization strategies as a case of mission-oriented policy-A case study on the emergence of new policy practices, Industrial and Corporate Change, 27(5), pp. 817-832. https://doi.org/10.1093/icc/dty030

FORAY, D. - DAVID, P. A. - HALL, B. (2009): Smart Specialisation - The Concept. Knowledge Economists Policy Brief, No. 9., p.5.

FORAY, D. - GODDARD, J. - BELDARRAIN, X. G. - LANDABASO, M. - MCCANN, P. MORGAN, K. - NAUWELAERS, C. - ORTEGA-ARGILÉS, R. (2012): Guide to Research and Innovation Strategies for Smart Specialisation (RIS 3), European Commission, p.122.

G. FEKETE É. (2008): A fejlődés és versenyképesség értelmezése kevésbé fejlett térségekben. In Lengyel I. - Lukovics M. (szerk.): Kérdőjelek a régiók gazdasági fejlődésében, JATEPress, pp. 130-152.

G. FEKETE É. (2015): A társadalmi innovációk a felzárkóztatás szolgálatában, Miskolci Egyetem Gazdaságtudományi Kar, Miskolc, p.210.

GRIGOLINI, M. - PANCOTTI, C. - SIRTORI, E. - VIGNETTI, S. (2015): A place-based strategy to smart specialisation: The case of Apulia, Centre for Industrial Studies, working paper 1., p.24.

HÁMORI B. - SZABÓ K. (2018): Innováció és hálózat, Educatio, 27(2), pp. 208-224. https://doi.org/10.1556/2063.27.2018.2.4

HORVÁTH K. (2004): Az innováció-alapú regionális fejlesztés lehetőségei Magyarországon, Tér és Társadalom, XVIII (4), pp. 29-49.

KATONÁNÉ KOVÁCS J. - VARGA E. - NEMES G. (2017): Fókuszban a társadalmi innováció folyamata a magyar vidéken, Észak-magyarországi Stratégiai Füzetek, XIV.(1), pp. 6 19.

KOCZISZKY GY. - VERESNÉ SOMOSI M. - BALATON K. (2017): A társadalmi innováció vizsgálatának tapasztalatai és fejlesztési lehetőségei, Vezetéstudomány, XLVIII(6-7.), pp.15-19. https://doi.org/10.14267/VEZTUD.2017.06.02

KORNAI J. (1999): A rendszerparadigma, Közgazdasági Szemle, XLVI. évf.(július-augusztus), pp.585-599.

KOZMA T. - FLÓRA G. - POLÓNYI I. - REISZ R. (szerk.) (2015). Tanuló régiók Magyarországon-Az elmélettől a valóságig, Debreceni Egyetem Felsőoktatási K\&F Központ, Debrecen, p.297. 
LENGYEl I. (2018): Az intelligens szakosodási stratégiák alapjai, különös tekintettel az egészségiparra. In Lengyel I. (szerk): Térségek növekedése és fejlődése, JATEPress, Szeged, pp. 11-35.

LIPTÁK K. - HORVÁTH K. (2018): Társadalmi innovációk szerepe a foglalkoztatáspolitikában és a vidékfejlesztésben, Észak-magyarországi Stratégiai Füzetek, XV.(3), pp. 55-68.

MARIMON, R. - DE GARCA CARVALHO, M. (2008): Governance and co-ordination of S\&T policies in the European Research Area.

MCCANN, P. - ORTEGA-ARGILÉS, R. (2015): Smart Specialization, Regional Growth and Applications to European Union Cohesion Policy, Regional Studies, 49(8), pp.12911302. https://doi.org/10.1080/00343404.2013.799769

NAGY Sz. (2019): A digitális társadalmi innováció, Észak-magyarországi Stratégiai Füzetek XVI. (1), pp.76-84.

NEMES G. - VARGA Á. (2015a): A magyar mezőgazdasági tudásrendszer intézményei és változásai, MTA Közgazdaság- és Regionális Tudományi Kutatóközpont, Közgazdaságtudományi Intézet, Budapest, p.18.

NEMES G. - VARGA Á. (2015b): Társadalmi innováció és társadalmi tanulás a vidékfejlesztésben-Sikerek, problémák, dilemmák. In: Veresné Somosi M. - Lipták K. (szerk.): „Mérleg és Kihívások” IX. Nemzetközi Tudományos Konferencia = „Balance and Challenges" IX. International Scientific Conference: A Gazdaságtudományi Kar megalapításának 25. Évfordulója alkalmából, Miskolci Egyetem Gazdaságtudományi Kar, Miskolc, pp.434-444.

NGM (Nemzetgazdasági Minisztérium) (2013): S3 Fehér Könyv: Magyarország intelligens szakosodási irányai, társadalmi egyeztetésre szánt változat, p.79.

NIH (2014): Nemzeti Intelligens Szakosodási Stratégia, Nemzeti Innovációs Hivatal, p.91.

NOGUEIRA, C. - PINTO, H. - SAMPAIO, F. (2017): Social innovation and smart specialisation: Opportunities for Atlantic Regions. European Public \& Social Innovation Review, 2(2), pp. $42-56$.

ORTEGA-ARGILÉS, R. (2012): The transatlantic porductivity gap: A survey of the main causes, Journal of Economic Surveys, 26(3), pp. 395-419. https://doi.org/10.1111/j.14676419.2012.00725.x

PAKUCS J. - PAPANEK G. (szerk.). (2006): Innováció menedzsment kézikönyv, Magyar Innovációs Szövetség, Budapest, p.233.

ROMER, P. (2000): Should the government subsidize supply or demand in the market for scientists and engineers?, Innovation Policy and the Economy, 1, pp. 221-252.

SZALAVETZ A. (2004): Technológiai fejlődés, szakosodás, komplementaritás, szerkezetátalakulás, Közgazdasági Szemle, LI. évf.(április), pp. 362-378.

VAN ARK, B. - O’MAHONY, M. - TIMMER, M. P. (2008): The Productivity Gap between Europe and the United States: Trends and Causes, Journal of Economic Perspectives, 22(1), pp. 25-44.

VAS Z. - BAJMÓCY Z. (2012): Az innovációs rendszerek 25 éve, Közgazdasági Szemle, 59(11), pp. 1233-1256. 